\title{
REWINDYKACJA MIENIA KOŚCIOLA EWANGELICKO-UNIJNEGO NA PRZYKŁADZIE WOJEWÓDZTWA WIELKOPOLSKIEGO
}

\section{WSTĘP}

Celem niniejszego artykułu jest omówienie problematyki związanej z rewindykacją mienia, które przed II wojną światową stanowiło własność Kościoła Ewangelicko-Unijnego (KEU). Przepisy regulujące powyższą kwestię zostały bowiem ustanowione przez ustawodawcę w sposób nieprecyzyjny, co rodzi liczne wątpliwości w zakresie ich interpretowania oraz stosowania. Co ważne, praktyka orzecznicza powołanej w tym celu Komisji Regulacyjnej ds. majątku Kościoła Ewangelicko-Augsburskiego w RP pokazuje, że rewindykacja mienia kościelnego stanowi istotny problem, który dotyka zarówno Skarb Państwa, jak i samorząd terytorialny. Liczne roszczenia reprywatyzacyjne, w szczególności dotyczące nieruchomości miejskich lub gminnych, stanowią zagrożenie dla płynności i integralności budżetów samorządu. Wynika to z faktu, że nieruchomości objęte żądaniami reprywatyzacyjnymi zostały w wielu przypadkach nabyte ex lege przez samorządy. Dla realizacji przedmiotowego założenia wykorzystana zostanie metoda formalno-dogmatyczna oraz historyczno-porównawcza ${ }^{1}$. Przeprowadzenie pracy porównawczej jest uzasadnione tym bardziej, że omówienie w opracowaniu tak złożonej problematyki wymaga odniesienia się do aspektu historyczno-społecznego w zakresie, w jakim kształtuje interes prawny do wniesienia roszczenia rewindykacyjnego.

\section{UJECCIE PROBLEMATYKI W RAMACH ASPEKTU HISTORYCZNO-SPOŁECZNEGO}

Do wybuchu II wojny światowej na terenach II RP funkcjonowało 5 Kościołów ewangelickich ${ }^{2}$, w skład których wchodził: Kościół Ewangelicko-Augsburski w RP (KEA), Kościół Ewangelicko-Unijny na Ziemiach Zachodnich, Kościół Staroluterski, Kościół Ewangelicki Augsburskiego i Helweckiego Wyznania oraz Kościół Ewangelicko-Unijny na polskim Górnym Śląsku³. Najbardziej

\footnotetext{
1 Przyjmując założenia metodologiczne teorii (koncepcji) derywacyjnej - por. Zieliński (2008).

2 Zob. np. Chabasińska (2009): 37-38. Według spisu powszechnego z 1931 r. w Polsce zamieszkiwało ok. 840 tys. protestantów - Tomaszewski (1985): 37-38.

3 Zob. np. Sławiński (2009): 257-259.
} 
liczny spośród wymienionych Kościołów był KEA; w tamtym okresie miał ok. 456 tys. wyznawców ${ }^{4}$. Kościół ten funkcjonował głównie na terenach dawnego zaboru rosyjskiego. Odmiennie przedstawiała się liczba wyznawców na terenach zaboru pruskiego, w szczególności w Wielkopolsce oraz na Pomorzu, gdzie dominującym Kościołem protestanckim był KEU (ok. 300 tys. wyznawców). Należy podkreślić, że o ile wyznawcami KEA byli w 60\% Niemcy, o tyle w przypadku KEU Niemcy stanowili co najmniej $95 \%{ }^{5}$.

Poznańscy ewangelicy przed wybuchem II wojny światowej tworzyli nieliczna grupę wyznawców. Szacuje się, że było to ok. 7 tys. osób, co stanowiło zaledwie ok. 2,6\% ogółu mieszkańców miasta ${ }^{6}$. Podstawą funkcjonowania tej niewielkiej grupy wyznaniowej były struktury kościelne ukształtowane jeszcze w okresie zaboru pruskiego, czyli w wieku XIX i na początku XX, kiedy liczba ewangelików w stolicy Wielkopolski sięgała 50 tys. (30\% mieszkańców miasta $)^{7}$. Zdecydowana większość lokalnych Niemców należała do KEU. W związku z odzyskaniem niepodległości z Polski do Rzeszy wyjechało ponad 40 tys. niemieckich protestantów, natomiast w Poznaniu pozostało ok. 6 tys. ewangelików unijnych ${ }^{8}$. Warto dodać, że analogicznie do KEU, KEA w okresie II RP posiadał w Poznaniu zaledwie ok. 200-300 wyznawców.

Co ważne, KEU w okresie II RP w znaczny sposób podkreślał swoje przywiązanie do niemieckich korzeni, w tym do Kościoła niemieckiego. Jak wskazuje Elżbieta Alabrudzińska, proces izolacji ewangelików niemieckich związany był z wpływem wydarzeń I wojny światowej, a potem coraz bardziej zacieśniających się kontaktów z protestantami niemieckimi byłej dzielnicy pruskiej. Podkreślenia wymaga fakt, że o ile przedstawiciele władz zwierzchnich KEU, ewangelickiego augsburskiego i helweckiego wyznania oraz staroluterańskiego podkreślali swoją niemiecką tożsamość narodową i działali jednoznacznie w kierunku jej wzmocnienia wśród wiernych, o tyle zwierzchnictwo KEA dążyło do kształtowania ideałów polskiego ewangelicyzmu. Różnice w tym zakresie były na tyle duże, że w relacjach między KEA a KEU, a także w samym środowisku KEU można zauważyć liczne napięcia oraz spory, które przejawiały w postaci wysokich cen najmu kościołów ewangelicko-unijnych, dyktowanych przez niemieckich współwyznawców z KEU w stosunku do polskich współwyznawców z KEU9, czy też

${ }^{4}$ Sławiński (2010): 225.

${ }^{5}$ Sławiński (2010): 225.

${ }^{6}$ Zob. Kiec (2009): 79-80.

${ }^{7} \mathrm{~W}$ ocenie prezydenta Poznania Cyryla Ratajskiego z miasta wyjechać mogło nawet 63 tys. Niemców; Dworecki (1994): 126.

${ }^{8}$ Kiec (2015): 299; podkreśla, że zgodnie z spisem powszechnym w 1931 r. ewangelików różnych denominacji i narodowości było łącznie 6720 (Statystyka Polski, Seria C, z. 74. Warszawa 1938: 11).

${ }^{9} \mathrm{~W}$ roku $1923 \mathrm{r}$. delegacja niemieckiej parafii i polskiego zboru spotkały się kilkukrotnie celem uzgodnienia warunków najmu obiektów wchodzących w skład parafii św. Łukasza, która znajdowała się na poznańskich Jeżycach. Negocjacje zakończyły się fiaskiem, ponieważ - jak wskazał A. Rhode (proboszcz parafii Chrystusa w Poznaniu i superintendent okręgu Poznań I w latach 1920-1941) - „parafialni negocjatorzy są przedsiębiorcami i potraktowali kościół jak fabrykę albo dom na wynajem, czyli według materialnej wartości” - Kiec (2015): 365. 
publicznych ataków (np. w literaturze przedmiotu) na superintendenta Juliusza Burschego ${ }^{10}$.

Można postawić tezę, że na skutek powyższych przemian społeczno-kulturowych, ewangelicy niemieccy wchodzący w skład KEU dążyli do podkreślania swojej łączności z macierzystym Kościołem w Rzeszy. Warto dodać, że następstwem powyższego procesu było ukształtowanie się nacjonalizmu Niemców w Polsce, co doprowadziło do napiętych stosunków w relacjach z państwem ${ }^{11}$. Jednym z rezultatów przedstawionej kwestii było przejęcie 10 października 1924 r. przez Polski Urząd Likwidacyjny internatu Paulinium, który znajdował się na terenach parafii wildeckiej w Poznaniu ${ }^{12}$.

Zajęcie Polski w 1939 r. przez III Rzeszę zostało przez zdecydowaną większość niemieckich członków KEU przyjęte z zadowoleniem, o ile nie z entuzjazmem $^{13}$. Olgierd Kiec wskazuje, że niemieccy ewangelicy wkroczenie Wehrmachtu do Polski traktowali wręcz jako wyzwolenie spod „dwudziestoletniego polskiego jarzma"14. Przeważająca część aktualnej Wielkopolski znalazła się w granicach okręgu Rzeszy „Kraj Warty”, w którym pod przewodnictwem namiestnika Arthura Greisera realizowany był z niezwykłym okrucieństwem i konsekwencja plan całkowitej germanizacji ludności przez eksterminację, a także wysiedlenie ludności polskiej ${ }^{15}$ oraz osiedlanie Niemców. Należy odnotować, że Greiser realizował również antyreligijną politykę eliminacji z życia publicznego Kościołów, która dotknęła także KEU. W szczególności przejęta została np. część nieruchomości należących do Kościołów (z wyłączeniem świątyń i domów parafialnych), w tym cmentarze wraz kaplicami ${ }^{16}$. W okresie okupacji, z uwagi na osiedlanie się Niemców oraz grup osadników pochodzących z państw bałtyckich (np. z terenów Estonii), liczba członków parafii KEU w Poznaniu ponownie wzrosła w ciagu kilku miesięcy z niecałych 7 tys. do ponad 50 tys. $^{17}$

W związku z masową ucieczką Niemców przed frontem i Armią Czerwona, śmiercią wyznawców w trakcie działań wojennych, a następnie akcją wysiedleńczą KEU utracił w Polsce wyznawców i zaprzestał działalności ${ }^{18}$. Warto dodać, że mienie KEU pozostawione zostało w wielu przypadkach bez jakiejkolwiek opieki ${ }^{19}$, przy tym jego część uległa zniszczeniu w trakcie działań wojennych albo została samowolnie zajęta lub zagrabiona przez III Rzeszę, osoby trzecie i Armię Czerwona. Jednak jego większość w latach 1945-1947 dostała

${ }^{10}$ Do głównych adwersarzy J. Burschego należeli: Kleindenst, Wagner (1985): 25-26; Schmidt (1992): 8-10. Burschemu zarzucano w szczególności przymusową polonizację narodowości niemieckiej.

11 Zob. np. Grelewski (1937): 45-48.

12 Kiec (2015): 370.

13 Kiec (2009b): 82; (2015): 403-407; Sławiński (2009): 359.

${ }^{14}$ Kiec (2009b): 82; (2015): 403-407; Sławiński (2009): 359.

15 Por. np. Pawlicki (2014): 82-86.

16 Kiec (2009b): 88.

17 Kiec (2009b): 84.

18 Por. Pietrzak (2013): 195-196; Chabasińska (2009): 47; Sławiński (2010): 227-228; Kiec (2015): 436-439; Sławiński (2008b): 359.

19 Sławiński (2007): 264. 
się we władanie odpowiednich organów państwowych ${ }^{20}$ - zostało przekazane przede wszystkim Kościołowi katolickiemu oraz różnego typu instytucjom, w tym oświatowym i służby zdrowia. Przy czym należy wskazać, że Kiec błędnie przyjmuje, że m.in. Zakład Diakonis (aktualnie Szpital Kliniczny im. Heliodora Święcickiego Uniwersytetu Medycznego w Poznaniu) został przejęty przez polskie organy administracji publicznej. Warto zauważyć, że w wielu przypadkach na terenach województwa wielkopolskiego nieruchomości przejmowane były pierwotnie przez Armię Czerwona, a następnie, po wymarszu wojsk ZSRR w rejony działań wojennych i okupacyjnych, przekazywane we władanie właściwych organów administracji publicznej.

Aktami prawnymi, które regulowały problematykę związaną z ewangelicką społecznością niemiecką były: dekret $\mathrm{PKWN}^{21}$ z 4 listopada 1944 r. o środkach zabezpieczajacych w stosunku do zdrajców narodu'22; dekret z 28 lutego 1945 r. o wyłączeniu ze społeczeństwa polskiego wrogich elementów ${ }^{23}$ (zastąpiony przez ustawę z 6 maja $1945 \mathrm{r}^{24}$ ); dekret z 28 czerwca $1946 \mathrm{r}$. o odpowiedzialności karnej za odstępstwo od narodowości w czasie wojny 1939-1945²5; dekret z 13 września 1946 r. o wyłączeniu ze społeczeństwa polskiego osób narodowości niemieckiej ${ }^{26}$. Podstawa prawną przejęcia nieruchomości społeczności ewangelickiej był dekret z 2 marca 1945 r. o majątkach opuszczonych i porzuconych ${ }^{27}$. Dekret ten utracił moc prawną w wyniku uchwalenia ustawy z 6 maja 1945 o majatkach opuszczonych i porzuconych ${ }^{28}$.

\section{NASTĘPSTWO PRAWNE KOŚCIOLA EWANGELICKO-AUGSBURSKIEGO}

Powyżej przedstawione rozważania natury historyczno-społecznej są istotne z punktu widzenia możliwości dochodzenia roszczeń reprywatyzacyjnych przez następcę prawnego KEU - tj. KEA. W orzecznictwie i literaturze przedmiotu pojawiły się bowiem wątpliwości co do tego, czy jeśli KEA nie nabył własności nieruchomości stanowiącej własność KEU, zwłaszcza na podstawie art. 1 ust. 2 dekretu z 19 września 1946 r. o zmianie dekretu Prezydenta Rzeczypospolitej z 25 listopada 1936 r. o stosunku Państwa do Kościoła Ewangelicko-Augsburskiego w Rzeczypospolitej Polskiej ${ }^{29}$ albo art. 2 ust. 1 ustawy z 4 lipca 1947 r. w sprawie zmiany dekretu Prezydenta Rzeczypospolitej

\footnotetext{
${ }^{20}$ Okręgowego Urzędu Likwidacyjnego w Poznaniu.

21 Polski Komitet Wyzwolenia Narodowego.

${ }^{22}$ Dz. U. Nr 11, poz. 54.

${ }^{23}$ Dz. U. Nr 7, poz. 30.

${ }_{24}$ Dz. U. Nr 17, poz. 96.

25 Dz. U. Nr 41, poz. 237.

26 Dz. U. Nr 55, poz. 310.

27 Dz. U. Nr 9, poz. 45 (dalej jako: dekret o majątkach opuszczonych).

28 Dz. U. Nr 17, poz. 97 (dalej jako: ustawa o majątkach opuszczonych).

${ }^{29}$ Dz. U. Nr 54, poz. 304.
} 
z 25 listopada 1936 r. o stosunku Państwa do Kościoła Ewangelicko-Augsburskiego w Rzeczypospolitej Polskiej ${ }^{30}$, to może skutecznie na podstawie przepisu art. 40 ust. 1 pkt 4) ustawy z 13 maja 1994 r. o stosunku Państwa do Kościoła Ewangelicko-Augsburskiego w Rzeczypospolitej Polskiej ${ }^{31}$ domagać się przywrócenia własności nieruchomości ${ }^{32}$. W ocenie autora należy zanegować taką możliwość, ponieważ przywrócenie własności, biorąc pod uwagę znaczenie terminu „przywrócić”, może nastapić jedynie na rzecz podmiotu, któremu to prawo wcześniej przysługiwało. W wyroku z 26 września 2003 r. Są Najwyższy podniósł, że: „w myśl art. 3 powołanego dekretu Prezydenta Rzeczypospolitej z roku 1936 KEA tworzyły parafie ewangelicko-augsburskie na całym obszarze państwa. W skład tego Kościoła wchodziły również parafie (gminy, zbory) luterskie i augsburskie, które należały do KEU oraz Kościoła Staroluterańskiego i Ewangelickiego Kościoła wyznań augsburskiego i helweckiego, a nadto Bracia Morawscy. [...] Zachodzi tu wszak nie następstwo prawne w ścisłym tego słowa znaczeniu, ale określone ustawą uprawnienie do przywrócenia własności nieruchomości uprzednio należącej do osoby prawnej tego samego Kościoła. Ustawa nie ogranicza nabycia roszczenia o przywrócenie własności nieruchomości utraconej od tego, czy nieruchomość ta uprzednio należała do osoby prawnej występującej z roszczeniem" ${ }^{33}$.

Odmienne stanowisko przedstawił Wojciech Sławiński, jak się wydaje właściwe - opiera się na treści art. 40 ust. 1 u.s.p.KEA ${ }^{34}$ w zw. z art. 39 ust. 1 pkt 2) u.s.p.KEA i wskazuje, że ustawodawca wyraźnie przesądził „o przywróceniu własności, a nie o przekazaniu KEA całego majątku innych nieistniejacych Kościołów ewangelickich ${ }^{35}$. Należy bowiem podkreślić, że przywrócona miała zostać własność nieruchomości byłych kościołów ewangelickich, która KEA otrzymał z mocy prawa na podstawie dekretu Prezydenta z 19 września 1946 r. i ustawy z 4 lipca 1947 r., a które zostały mu później przez władze komunistyczne bezprawnie odebrane. Wykładnia art. 40 ust. 1 u.s.p.KEA w omawianym zakresie nie budzi raczej wątpliwości. Gdyby bowiem intencja ustawodawcy było przywrócenie własności wyłącznie nieruchomości stanowią-

${ }^{30}$ Dz. U. Nr 52, poz. 272.

31 T.jedn.: Dz. U. 2015, poz. 43 (dalej jako: u.s.p.KEA).

32 Zob. Binemann-Zdanowicz (2009): 383-385; także Cebula (2017): 153-156; wyrok SN z 26 września 2003 r., IV CKN 487/01, Lex nr 1634357; odmiennie Sławiński (2008b): 265-267.

33 Wyrok SN z 26 września 2003 r., IV CKN 487/01, Lex nr 1634357.

${ }^{34}$ Przepis art. 40 ust. 1 u.s.p.KEA stanowi o tym, że na wniosek kościelnej osoby prawnej wszczyna się postępowanie (dalej jako: postępowanie regulacyjne) w przedmiocie przywrócenia własności przejętych na rzecz Skarbu Państwa nieruchomości lub ich części, o których mowa w art. 39 ust. 1 pkt 1) i 2): 1) rolnych i leśnych przejętych w toku wykonania ustawy z 20 marca 1950 r. o przejęciu przez Państwo dóbr martwej ręki, poręczeniu proboszczom posiadania gospodarstw rolnych i utworzeniu Funduszu Kościelnego (Dz. U. Nr 9, poz. 87 ze zm.), jeżeli nie wydzielono z nich należnych, w myśl tej ustawy, gospodarstw rolnych proboszczów; 2) wywłaszczonych, jeżeli odszkodowanie nie zostało wypłacone lub podjęte; 3) przejętych na podstawie dekretu z 26 października 1945 r. o własności i użytkowaniu gruntów na obszarze miasta stołecznego Warszawy (Dz. U. Nr 50, poz. 279), z zastrzeżeniem ust. 2; 4) przejętych we władanie państwowych jednostek organizacyjnych bez tytułu prawnego, bez względu na późniejsze ustawodawstwo konwalidujące to przejęcie.

35 Sławiński (2008): 352; także (2007). 
cych w przeszłości własność KEA, wówczas zbędne byłoby odesłanie w art. 40 ust. 1 u.s.p.KEA do przepisu art. 39 ust. 1 pkt 2) u.s.p.KEA, dotyczącego mienia ewangelicko-unijnego ${ }^{36}$.

\section{POSTĘPOWANIE REGULACYJNE}

W celu wynagrodzenia strat poniesionych przez KEA ustawodawca uchwalił ustawę, która uprawnia go do dochodzenia roszczeń majątkowych na terenie byłej Drugiej Rzeczypospolitej w trybie administracyjnym - postępowaniu regulacyjnym ${ }^{37}$, a w przypadku nieuzgodnienia orzeczenia przez Komisję Regulacyjna - na drodze sądowej ${ }^{38}$. Adresatem tych roszczeń jest Skarb Państwa lub samorzą terytorialny.

Jak wskazano w uzasadnieniu omawianego aktu prawnego, ustawodawca podniósł, że: „w tym stanie rzeczy nie jest możliwe określenie skutków finansowych związanych z regulacją praw majątkowych wynikających z projektu ustawy. Należy jednak zaznaczyć, że możliwość wypłaty odszkodowań dotyczy wyłącznie nieruchomości ziemskich przejętych na własność Państwa z naruszeniem cytowanej ustawy o dobrach martwej ręki. W pozostałych przypadkach przewiduje się wyłącznie możliwość fizycznego zwrotu bądź przekazania nieruchomości pod warunkiem, że są one niezbędne do celów kultowych, charytatywno-opiekuńczych lub oświatowo-wychowawczych. Według bardzo szacunkowego rozeznania można także stwierdzić, że skala roszczeń rewindykacyjnych Kościoła będzie niewielka, ograniczają się do kilkunastu nieruchomości, przy czym roszczenia te dotyczyć będą głównie obiektów sakralnych i związanych z nimi obiektów oraz, w kilku przypadkach, gospodarstw rolnych

${ }^{36}$ KEA nie posiada legitymacji prawnej, aby występować z roszczeniem rewindykacyjnym w stosunku do całego mienia pounijnego - jako mienia należącego do „tego samego Kościoła” (podobnie Sławiński [2008b]: 267). Tym samym roszczenia rewindykacyjne KEA w trybie administracyjnym czy cywilnym są w części bezprzedmiotowe.

${ }^{37}$ Charakter prawny postępowań dotyczących regulacji spraw majątkowych różnych Kościołów i związków wyznaniowych budzi w orzecznictwie wątpliwości. Pierwotnie przeważał pogląd, że postępowania prowadzone przez komisje regulacyjne nie miały charakteru postępowań administracyjnych. Ostatnio jednak coraz większe uznanie zyskuje pogląd przeciwny. Należy zauważyć, że Trybunał Konstytucyjny w uzasadnieniu wyroku z 13 marca 2013 r. w odniesieniu do Komisji Regulacyjnej do spraw Gmin Wyznaniowych Żydowskich (dalej: Komisja ds. Żydowskich), działającej w analogicznym trybie i na podobnych zasadach, co Komisja Regulacyjna do spraw KEA, stwierdził, że działalność Komisji ds. Żydowskich stanowi przejaw szeroko pojętej działalności administracji publicznej, Komisję ds. Żydowskich ulokowano bowiem w strukturze organów administracji państwowej (wyrok TK z 13 marca 2013 r., K 25/10, Lex nr 1294138; także wyrok NSA z 28 kwietnia 2017 r., II OSK 2099/15, Lex nr 2315653). Sformułowanie o niedopuszczalności wniesienia odwołań od tych orzeczeń, zawarte w ustawach uprawniających związki wyznaniowe do rewindykacji utraconego mienia, oznacza jedynie, że postępowania te mają charakter jednoinstancyjny, co nie wyłącza zaskarżania wydanych w ich toku orzeczeń do sądu administracyjnego lub w trybie postępowania o stwierdzenie nieważności.

${ }^{38}$ Zob. Binemann-Zdanowicz (2009): 384. 
przejętych w trybie cyt. ustawy o dobrach martwej ręki, zwłaszcza na terenie Ślaska Cieszyńskiego, obejmujacych łącznie ok. 100 ha [...]"39.

Rzeczywistość pokazuje, że skutki u.s.p.KEA są zgoła odmienne od zakładanych. W ocenie Dawida Binemanna-Zdanowicza do Komisji Regulacyjnej wpłynęło 1200 wniosków, dotyczących w znacznym stopniu terenów niezabudowanych oraz dawnych cmentarzy ewangelickich ${ }^{40}$. Należy nadmienić, że przed Komisją Regulacyjną wciąż toczy się wiele postępowań regulacyjnych, którymi objęte są także nieruchomości położone na terenach województwa wielkopolskiego. Co ważne, w wielu przypadkach, mimo upływu ponad 20 lat od uchwalenia u.s.p.KEA, postępowania regulacyjne sa na wstępnym etapie rozpoznania, co prowadzi do wniosku, że trudny do przewidzenia jest przybliżony termin wyczerpania roszczeń KEA ${ }^{41}$. Jednakże Binemann-Zdanowicz podkreślił, że: „samoograniczenie się Kościoła było wyrazem obywatelskiej postawy wiernych i władz Kościoła Ewangelicko-Augsburskiego, by nie obciążać nadmiernie finansowo samorządów i osób prawnych Skarbu Państwa skutkami bezprawia z lat 1944-1945, a jednocześnie zabezpieczyć podstawowe potrzeby Kościoła, niezbędne do jego funkcjonowania" ${ }^{42}$. W tym zakresie nie można się zgodzić z tezą postawioną przez Binemanna-Zdanowicza, ponieważ - jak wynika z dotychczasowej praktyki Komisji Regulacyjnej - KEA zainteresowany jest zarówno nieruchomościami należącymi bezpośrednio do dawnego KEU (np. park Manitiusa zlokalizowany u zbiegu ulic Grunwaldzkiej i Reymonta w Poznaniu ${ }^{43}$ ), jak i do osób trzecich ${ }^{44}$. Sławiński podnosi również istotną kwestię związaną z objęciem postępowaniem regulacyjnym tych nieruchomości, które nie były własnością parafii KEU. Wskazuje też, że w analizowanych przypadkach w stosunku do nieruchomości objętych postępowaniem regulacyjnym wydawano orzeczenia o nieodpłatnym przekazaniu własności nieruchomości „należących do takich kościelnych osób prawnych, jak diakonaty, czy też należące do szkół ewangelickich”45. Powyższe wattpliwości można także odnieść do postępowań regulacyjnych, którymi objęte sa nieruchomości wielkopolskie ${ }^{46}$.

39 Zob. uzasadnienie projektu ustawy o stosunku Państwa do Kościoła Ewangelicko-Augsburskiego w Rzeczypospolitej Polskiej (druk sejmowy nr 69/II kadencja), <http://www.sejm.gov.pl> [dostęp: 5.05.2018]; również P. Stachańczyk podczas debaty sejmowej podnosił, że „roszczenia rewindykacyjne Kościoła w całym kraju ograniczają się do kilkunastu nieruchomości i gospodarstw rolnych o łącznym obszarze ok. 100 ha (wypowiedź z debaty sejmowej - stenogram posiedzenia sejmu z 4 lutego 1993 r.; 36 posiedzenie sejmu, pierwszy dzień obrad, 6 punkt porządku dziennego).

40 Binemann-Zdanowicz (2009): 383.

41 Negatywnie również odniósł się Sławiński (2008a): 357.

42 Sławiński (2008a): 357.

${ }^{43}$ Postępowanie regulacyjne o sygn. W.KR-I-3621/IV/788/96. Informacja uzyskana w trybie dostępu do informacji publicznej z 3 stycznia 2018 r.

44 Zob. Sławiński (2008a): 359.

45 Sławiński (2008a): 360-361. Archiwum Komisji Regulacyjnej, W.Kr-II-3621/IV/385/96; W.KR-II-3621/IV/390/86; W.KR-II-3621/IV/166/96; W.KR-II-3621/IV/167/96.

${ }_{46}$ Postępowanie regulacyjne o sygn. W.KR-I-3621/IV/787/96 - postępowanie w sprawie nieodpłatnego przekazania własności nieruchomości położonej w Poznaniu przy ul. Przybyszewskiego (dawniej szpital należący do ewangelickiego Zakładu Diakonis), czy też sygn. W-KR-I-3621/ 


\section{MODELE REWINDYKACJI MIENIA EWANGELICKIEGO}

Trzy modele rewindykacji nieruchomości, które zakłada u.s.p.KEA, zostały uregulowane w przepisach art. 39 , art. 40 , art. $41^{47}$ oraz art. 45 a. Pierwszy z modeli ustawodawca uregulował w przepisie art. 39 u.s.p.KEA, który stanowi o tym, że uwłaszczenie kościelnych osób prawnych następuje z mocy samego prawa. Jednakże nabycie własności nieruchomości wymaga wydania deklaratoryjnej decyzji przez właściwego wojewodę, potwierdzającej okoliczność nabycia. Aby doszło do rewindykacji mienia na gruncie przedmiotowego przepisu, muszą zostać spełnione kumulatywnie dwie przesłanki. Pierwsza przesłanka jest charakterystyczna dla wszystkich aktów prawnych regulujacych zagadnienie reprywatyzacji mienia kościelnego, tj. pozostawanie przedmiotowej nieruchomości (w całości lub jej części) we władaniu kościelnej osoby prawnej w dniu wejścia w życie u.s.p.KEA. Druga przesłanka zaśs wymaga, aby nieruchomość objęta postępowaniem regulacyjnym: była własnością diecezji, parafii i filiałów wymienionych w wykazie stanowiącym załącznik do dekretu Prezydenta Rzeczypospolitej z 25 listopada 1936 r. o stosunku Państwa do KEA w Rzeczypospolitej Polskiej ${ }^{48}$ oraz diakonatów ${ }^{49}$ albo była własnościa parafii (gmin, zborów) KEU, Kościoła Staroluterskiego, Ewangelickiego Kościoła wyznań augsburskiego i helweckiego oraz Braci Morawskich (Hurnhutów) ${ }^{50}$, albo podlegały przepisom dekretu z 24 kwietnia 1952 r. o zniesieniu fundacji ${ }^{51}$, a zostały podręczone, pozostawione, wydzierżawione, wynajęte lub przekazane kościelnym osobom prawnym ${ }^{52}$, albo znajduja się na nich cmentarze lub obiekty sakralne oraz obiekty funkcjonalnie związane $\mathrm{z}$ obiektami sakralnymi; dotyczy to również obiektów położonych na obszarze miasta stołecznego Warszawy ${ }^{53}$.

W sytuacji braku możliwości nabycia nieruchomości z mocy prawa prawodawca ustanowił odmienną procedurę rewindykacji mienia - w drodze postę-

IV/781/96 - postępowanie w sprawie nieodpłatnego przekazania nieruchomości położonej w Poznaniu przy ul. Czarnieckiego (do czasu przejęcia nieruchomości na rzecz Skarbu Państwa, należąca do Ewangelickiego Związku Wychowawczego, a następnie do Nationalsozialistische Volkswohlfahrt w Berlinie - Narodowosocjalistyczna Dobroczynność, stowarzyszenie zapisane w Berlinie). Informacja o prowadzonym postępowaniu regulacyjnym uzyskana została w trybie dostępu do informacji publicznej z 3 stycznia 2018 r.

${ }_{47}$ Przepis art. 41 ust. 1 u.s.p.KEA stanowi o tym, że przedmiotem postępowania regulacyjnego może być również nieodpłatne przekazanie własności niepozostajacych $\mathrm{w}$ dniu wejścia $\mathrm{w}$ życie ustawy we władaniu kościelnych osób prawnych nieruchomości lub ich części: 1) o których mowa w art. 39 ust. 1 pkt 1-3); 2) będących uprzednio własnością parafii (gmin, zborów) ewangelickich, działających do 1945 r. na Ziemiach Zachodnich i Północnych, jeśli są one niezbędne na cele kultowe lub dla prowadzenia przez kościelne osoby prawne działalności oświatowo-wychowawczej, charytatywno-opiekuńczej i opiekuńczo-wychowawczej.

${ }_{48}^{4}$ Dz. U. Nr 88, poz. 613 ze zm.

${ }^{49}$ Art. 39 ust. 1 pkt 1) u.s.p.KEA.

${ }^{50}$ Art. 39 ust. 1 pkt 2) u.s.p.KEA.

${ }^{51}$ Dz. U. Nr 25, poz. 172 ze zm.

${ }_{52}$ Art. 39 ust. 1 pkt 3) u.s.p.KEA.

${ }^{53}$ Art. 39 ust. 1 pkt 4) u.s.p.KEA. 
powania regulacyjnego ${ }^{54}$, które skutkuje przywróceniem własności nieruchomości przejętej na własność Skarbu Państwa. Co ważne, przywrócenie własności odnosi się jedynie do nieruchomości (oraz ich części) wskazanych w art. 39 ust. 1 pkt 1) i 2) u.s.p.KEA i mających charakter rolnych i leśnych przejętych w toku wykonania ustawy z 20 marca 1950 r. o przejęciu przez państwo dóbr martwej ręki, poręczeniu proboszczom posiadania gospodarstw rolnych i utworzeniu Funduszu Kościelnego ${ }^{55}$, jeżeli nie wydzielono z nich niezależnych, w myśl tej ustawy, gospodarstw rolnych proboszczów, albo wywłaszczonych, jeżeli odszkodowanie nie zostało wypłacone lub podjęte, albo przejętych we władanie państwowych jednostek organizacyjnych bez tytułu prawnego, bez względu na późniejsze ustawodawstwo konwalidujące to przejęcie.

Należy podkreślić, że w sytuacji, gdy nie ma możliwości przywrócenia własności kościelnej osobie prawnej, „przyznaje się jej nieruchomość zamienna a jeśli nie jest to możliwe lub natrafia na trudne do przezwyciężenia przeszkody, odszkodowanie jest ustalana według przepisów o wywłaszczeniu nieruchomości" 56 .

Trzeci model nabycia nieruchomości regulują przepisy art. 41 i art. 45a u.s.p.KEA. Przepisy te odnoszą się do kwestii nieodpłatnego przekazania własności nieruchomości na rzecz KEA. Przy czym warto wskazać, że każdy z przedstawionych przepisów zawiera odmienne przesłanki.

Przepis art. 41 u.s.p.KEA dotyczy nieruchomości lub ich części niepozostających we władaniu kościelnych osób prawnych w dniu wejścia w życie ustawy. Co istotne, postępowanie regulacyjne może dotyczyć tych nieruchomości, które zostały wskazane w art. 39 ust. 1 pkt 1)-3) u.s.p.KEA oraz będących uprzednio własnością parafii ewangelickich, działajacych do 1945 r. na Ziemiach Zachodnich i Północnych, jeśli są one niezbędne do celów kultowych lub dla prowadzenia przez kościelne osoby prawne działalności oświatowo-wychowawczej, charytatywno-opiekuńczej i opiekuńczo-wychowawczej.

Odnosząc się do przytoczonych przesłanek, należy wskazać, że pierwsza kategoria nieruchomości odnosi się w szczególności do nieruchomości, które stanowiły własność wskazanych w art. 39 ust. 1 pkt 1)-2) u.s.p.KEA osób prawnych, np. parafii KEU. Można również zauważyć, że w zakresie omawianego przepisu ustawodawca nie zawarł przesłanki mającej na celu zbadanie podstawy nabycia nieruchomości przez Skarb Państwa.

Przepis art. 45a u.s.p.KEA stanowi o tym, że: „na wniosek Kościoła lub jego osób prawnych wojewoda lub inny organ wykonujacy w imieniu Skarbu Państwa prawa wynikające z własności nieruchomości albo organy gmin w zakresie swoich właściwości - mogą nieodpłatnie przekazać Kościołowi lub jego osobom prawnym własność nieruchomości lub ich części: jeżeli są one niezbędne do sprawowania kultu religijnego lub działalności kościelnych osób prawnych w zakresie charytatywno-opiekuńczym lub oświatowo-wychowawczym; $\mathrm{w}$ celu utworzenia lub powiększenia gospodarstwa rolnego parafii działają-

\footnotetext{
${ }^{54}$ Drugi model rewindykacji mienia na podstawie przepisów u.s.p.KEA.

55 Dz. U. Nr 9, poz. 87 ze zm.

${ }^{56}$ Art. 40 ust. 3 u.s.p.KEA.
} 
cych na Ziemiach Zachodnich i Północnych, o powierzchni do 15 ha użytków rolnych łącznie dla jednej parafii” ${ }^{57}$.

Na potrzeby niniejszego opracowania, w związku z licznymi wątpliwościami w zakresie interpretowania i stosowania przepisów omawianej u.s.p.KEA, zostana przeanalizowane w szczególności przepisy art. 40 oraz art. 41 u.s.p.KEA. Jak zostało to wskazane wcześniej, podstawą prawną większości postępowań w sprawie rewindykacji mienia KEU sa przepisy art. 40 oraz 41 u.s.p.KEA. W pozostałym zakresie przepisy nie uprawniają KEA do występowania z roszczeniami w stosunku do każdego rodzaju nieruchomości, które stanowiło przed przejęciem własność KEU. Warto nadmienić, że w toku prowadzonych przez Komisję Regulacyjną postępowań KEA wnosił o zmianę podstawy prawnej wniosku z przepisu art. 41 na przepis art. 40 u.s.p.KEA, który reguluje znacznie większy zakres form rewindykacyjnych na rzecz KEA. Z punktu widzenia problematyki procesowej należy zastanowić się, czy przedmiotowa czynność po upływie terminu do wniesienia wniosku jest prawnie dopuszczalna.

\section{ANALIZA PRZEPISU ART. 40 I ART. 41 U.S.P.KEA W ZAKRESIE FAKULTATYWNOŚCI STOSOWANIA}

Przepis art. 40 ust. 3 u.s.p.KEA stanowi o tym, że wnioski o wszczęcie postępowania regulacyjnego mogły być zgłaszane w terminie dwóch lat od dnia wejścia w życie tej ustawy (tj. do 11 lipca 1996 r.), natomiast roszczenia niezgłoszone w tym terminie wygasły. Należy zatem wskazać, że ustawa w zakresie przepisu art. 40 oraz art. 41 u.s.p.KEA zakłada dwa odrębne rodzaje roszczeń, oparte na odmiennych przesłankach i przewidujących różne świadczenia. Pierwszy rodzaj oparty jest na przesłankach ujętych w art. 40 ust. 1 u.s.p.KEA i w razie ich spełnienia wnioskodawca może żądać - na zasadach określonych w art. 40 ust. 1 i 3 u.s.p.KEA - przywrócenia własności przejętej na rzecz Skarbu Państwa nieruchomości, nieruchomości zamiennej albo odszkodowania ustalanego według przepisów o wywłaszczaniu nieruchomości. Drugi - wynika z art. 41 ust. 1 u.s.p.KEA i może prowadzić wyłącznie do nieodpłatnego przyznania własności nieruchomości. Treść przepisów u.s.p.KEA nie daje zatem podstaw do poglądu o istnieniu jednego roszczenia „regulacyjnego”, obejmujacego łącznie roszczenia ujęte w przepisach art. 40 i 41 u.s.p.KEA, dla którego skonkretyzowania i skutecznego zgłoszenia wystarczające było wskazanie przez wnioskodawcę jedynie nieruchomości nim objętej ${ }^{58}$. Na potrzeby niniejszej analizy należy odnieść się do postępowania rewindykacyjnego uregulowanego w ustawie z 17 maja 1989 r. o stosunku Państwa do Kościoła Ka-

57 Art. 45a u.s.p.KEA.

58 Odmienny pogląd prezentuje Binemann-Zdanowicz, w którego ocenie występowanie przez KEA z żądaniami opartymi na art. 41 ust. 1 pkt 1) u.s.p.KEA zostało „narzucone przez stronę rządową" (zob. Binemann-Zdanowicz [2009]: 385-390). 
tolickiego w Rzeczypospolitej Polskiej ${ }^{59}$. Warto podkreślić, że w orzecznictwie wykształcił się dominujący pogląd wskazujący, że żądanie z przepisu art. 63 u.s.p.KK należy traktować jako jedno roszczenie o skonkretyzowanie prawa. W związku z powyższym nie jest dopuszczalne przyznanie np. nieruchomości zamiennej, w sytuacji gdy kościelna osoba prawna jednoznacznie precyzuje żądanie przedmiotu postępowania regulacyjnego, np. o przywrócenie własności nieruchomości. W powyższym zakresie stanowisko zajął również SN w wyroku z 27 kwietnia 2012 r., w którym podniósł, że: „[...] z uwagi na zakaz wyrażony w art. $321 \S 1$ k.p.c. nie jest możliwe rozważenie pozostałych sposobów przeprowadzenia postępowania regulacyjnego, bowiem - wobec ostatecznego sprecyzowania żądania jako żądania przywrócenia własności upaństwowionej nieruchomości kościelnej - przyznanie nieruchomości zamiennej lub odszkodowania stanowiłoby wyjście ponad żądanie"60.

\section{BEZPRAWNE NABYCIE NIERUCHOMOŚCI NALEŻĄCYCH DO KEU}

Na wstępie warto wskazać na przedwojenne oraz powojenne ustawodawstwo, które regulowało problematykę związaną z zakresem kompetencji organów administracji publicznych do obejmowania pozostawionego bez opieki mienia nieruchomego ${ }^{61}$. W związku z podjętymi przez ustawodawcę aktami prawnymi organy administracji publicznej uprawnione były do objęcia w zarząd opuszczonych nieruchomości w celu ich zabezpieczenia. Ponadto ówczesne ustawodawstwo regulowało kwestę procedury rewindykacji mienia przez prawowitych właścicieli oraz jego zagospodarowanie do momentu przywrócenia posiadania osobom uprawnionym. Odnosząc się do badanej problematyki, należy uznać, że nieruchomości, których właścicielem był KEU, w związku z art. 40 ust. 1 pkt 4) u.s.p.KEA nie zostały przejęte bez tytułu prawnego. W niniejszym zakresie stanowisko zają również SN w uchwale z 21 grudnia 2006 r., w którym uznał, że omawiane przepisy „nie miały bezpośrednio charakteru nacjonalizacyjnego, a konieczność ustanawiania zarządu nieruchomości opuszczonych była i jest oczywista w świetle ogromu strat ludzkich i zniszczeń materialnych spowodowanych bezpośrednio przez okupanta i wskutek działań wojennych. Jeżeli nieruchomość była opuszczona, działanie ówczesnych władz polegające na obejmowaniu jej w zarząd nie może być poczytane za pozbawione tytułu prawnego"62. Jak wskazano wyżej, wiele nieruchomości należących

${ }_{59}$ T.jedn.: Dz. U. 2018, poz. 380 (dalej jako: u.s.p.KK). W zakresie przepisów art. 61 i 63 u.s.p.KK.

${ }^{60}$ Wyrok SN z 27 kwietnia 2012 r., V CSK 207/11, Lex nr 1168734.

${ }^{61}$ Dekret z 16 grudnia 1918 r. w przedmiocie ochrony majątku nieobecnych właścicieli, Dz. U. Nr 21, poz. 68.

${ }^{62}$ Uchwała SN z 21 grudnia 2006 r., III CZP 123/06, Lex nr 204938; także wyrok SN z 18 marca 2009 r., IV CSK 450/08, Lex nr 530584. 
do KEU na ziemiach II RP zostało opuszczonych, w szczególności w 1945 r. ${ }^{63}$ Sławiński podnosi również, że „przekazanie w zarząd i opiekę obiektów opuszczonych nie naruszało praw właścicieli, którym - zgodnie z dekretem o majątku opuszczonym - mogło być przywrócone posiadanie tych majątków, chyba że miały one szczególne znaczenie dla interesów państwa. Jeżeli po majątek nie zgłosiła się żadna osoba, względnie nikomu nie przywrócono prawa do posiadania, to Skarb Państwa względnie osoby lub instytucje, którym majątek przekazano w zarząd i użytkowanie, stawać się mieli właścicielem nieruchomości - majątku porzuconego już po latach pięciu, majątku opuszczonego po latach 20 , ruchomości po latach 10 , a dochodów po latach pięciu" ${ }^{4}$. W tym zakresie pojawia się również problematyka uznania za konwalidujący dekret o majątkach opuszczonych oraz ustawa o majątkach opuszczonych. Jednakże ze względu na objętość przedstawionego zagadnienia wymaga ono omówieniu w odrębnym opracowaniu.

Powyższe prowadzi do wniosku, że KEA rzadko będzie przysługiwało roszczenie $\mathrm{z}$ art. 40 ust. 1 pkt 4) u.s.p.KEA w odniesieniu do nieruchomości ewangelicko-unijnych, jego przesłanką jest bowiem bezprawność działania organów władzy państwowej.

\section{PODSUMOWANIE}

Analiza problematyki związanej z rewindykacją mienia KEU pozwala dojść do wniosku, że ustawodawca, przygotowując projekt omawianej u.s.p.KEA, popełnił liczne błędy legislacyjne, które skutkują wieloma rozbieżnościami zarówno w orzecznictwie, jak i doktrynie. Warto wskazać, że w analogicznych przepisach zawartych w u.s.p.KK oraz ustawy z 4 lipca 1991 r. o stosunku Państwa do Polskiego Autokefalicznego Kościoła Prawosławnego ${ }^{65}$ prawodawca w sposób transparenty i zrozumiały uregulował kwestię rewindykacji mienia na rzecz właściwego związku wyznaniowego. W związku z powyższym wskazane byłoby, w sytuacji występowania rozbieżności w zakresie stosowania analizowanych w niniejszym opracowaniu przepisów, wypracowanie przez Komisję Regulacyjną ds. KEA oraz sądy jednolitej linii orzeczniczej zgodnie metoda per analogiam, której punktem odniesienia byłyby przedstawione powyżej akty prawne. Zdaniem autora niewątpliwie umożliwiłoby to przyspieszenie pracy Komisji Regulacyjnej ds. KEA, a także zapewnienie pewności prawnej, co przekładałoby się na oszczędność środków budżetowych, w szczególności w mniejszych gminach.

Powyższe rozważania są również istotne $\mathrm{z}$ punktu widzenia art. 2 Konstytucji $\mathrm{RP}^{66}$, w zakresie, w jakim prawidłowo prowadzone postępowania regulacyjne prowadziłyby do niezwłocznego wyczerpania roszczeń rewindyka-

${ }^{63}$ Sławiński (2010): 227-228.

${ }^{64}$ Sławiński (2010): 230.

${ }_{65}$ T.jedn.: Dz. U. 2014, poz. 1726.

${ }^{66}$ Konstytucja Rzeczypospolitej Polskiej z 2 kwietnia 1997 r., Dz. U. Nr. 78, poz. 483 ze zm. 
cyjnych KEA. W szczególności należy mieć na uwadze fakt, że przedmiotowe postępowania prowadzone są przez Komisję Regulacyjną od dwudziestu lat, co prowadzi do jednoznacznego wniosku, że model reprywatyzacyjny oparty na postępowaniu regulacyjnym prowadzonym przez Komisję Regulacyjna jest nieefektywny i nieskuteczny. Jako odmienny i zarazem skuteczny można wskazać model reprywatyzacyjny ${ }^{67}$ przyjęty w postępowaniu zabużańskim, który do chwili obecnej umożliwił wyczerpanie większości zgłoszonych roszczeń (termin do zgłaszania roszczeń upłyną 31 grudnia 2008 r.). W związku z powyższym autor wyraża wątpliwość co do dalszego kontynuowania postępowań, które zmierzałyby do zaspokojenia wszystkich roszczeń KEA, i jako propozycję rozwiązania omawianej problematyki wskazuje model administracyjny, prowadzony przez posiadajacy do tego odpowiednie kompetencje organ administracji publicznej.

Beniamin Rozczyński

Uniwersytet im. Adama Mickiewicza w Poznaniu

beniamin.rozczynski@amu.edu.pl

https://orcid.org/0000-0003-2019-7923

Binemann-Zdanowicz, D. (2009). Roszczenia majątkowe Kościoła Ewangelicko-Augsburskiego w Rzeczypospolitej Polskiej w świetle ustawy z 13 maja 1994 r. o stosunku Państwa do Kościoła Ewangelicko-Augsburskiego w Rzeczypospolitej Polskiej, [w:] J. Kłaczkow (red.), Polski protestantyzm w czasach nazizmu i komunizmu. Toruń: 372-400.

Cebula, J. (2017). Ustawa o stosunku Państwa do Kościoła Ewangelicko-Augsburskiego w Rzeczypospolitej Polskiej, [w:] J. Cebula (red.), Prawo Kościoła Ewangelicko-Augsburskiego. Komentarz. Warszawa: 3-182.

Chabasińska, A. (2009). Polityka władz wobec mniejszości wyznaniowych w Polsce w latach 19451956. PWSZ IPiA Studia Lubuskie 5: 37-62.

Dworecki, Z. (1994). Poznań i poznaniacy w latach Drugiej Rzeczypospolitej 1918-1939. Poznań.

Grelewski, S. (1937). Wyznania protestanckie i sekty religijne w Polsce współczesnej. Lublin.

Kiec, O. (2009a). Ewangelicki Kościół Unijny w Polsce wobec „walki kościelnej” w Trzeciej Rzeszy 1933-1939, [w:] J. Kłaczkow (red.), Polski protestantyzm w czasach nazizmu i komunizmu. Toruń: 45-66.

Kiec, O. (2009b). Poznańscy ewangelicy w stolicy Kraju Warty (1939-1945), [w:] Okupacja II. Kronika Miasta Poznania 3: 79-93. <http://www.wbc.poznan.pl/dlibra/doccontent?id=161588> [dostęp: 2.05.2018].

Kiec, O. (2015). Historia protestantyzmu w Poznaniu od XVI do XXI wieku. Poznań.

Kleindenst, A., Wagner, O. (1985). Der Protestantismus in der Republik Polen 1918/19 bis 1939 im Spannungsfeld von Nationalitatenpolitik und Staatskirchenrecht, kirchlicher und nationaler Gegensatze, Marburg/Lahn.

Pawlicki, A. (2014). Procesy osób oskarżonych o popełnienie zbrodni nazistowskich w tzw. „Kraju Warty" przed sądami specjalnymi w latach 1945-1946. Poznań.

Pietrzak, M. (2013). Prawo wyznaniowe. Warszawa.

Schmidt, A. (1992). Bischof Dr. Julius Bursche. Kirchenmann und Patriot. Hannover.

Sławiński, W. (2007). Czasami i sądom, nawet najwyższego szczebla, zdarzają się pomyłki. Rzeczpospolita 1.03.2007, <http://archiwum.rp.pl/artykul/668339-Czasami-i-sadom-nawet-najwyzszego-szczebla-zdarzaja-sie-pomylki.html> [dostęp: 2.05.2018].

${ }^{67}$ Model ten oparty jest na prowadzonym przez właściwego wojewodę postępowaniu administracyjnym, zakończonym w drodze decyzji administracyjnej. 
Sławiński, W. (2008a). Działalność Komisji Regulacyjnej ds. Majątku Kościoła Ewangelicko-Augsburskiego w RP w świetle przepisów prawa i praktyki. Roczniki Nauk Prawnych 18(2): 349-365.

Sławiński, W. (2008b). Rewindykacja majątku Kościołów ewangelickich w świetle ustawodawstwa polskiego na przykładzie b. ewangelickich gmin kościelnych w Chełmży i Toruniu. Czasy Nowożytne 20: 252-270.

Sławiński, W. (2009). Spory o nieruchomości Kościołów ewangelickich w Polsce w latach 19451947 - ujęcie historyczno-prawne. Zarys zagadnienia, [w:] J. Kłaczkow (red.), Polski protestantyzm w czasach nazizmu i komunizmu. Toruń: 356-371.

Sławiński, W. (2010). Losy majątku poewangelickiego na wybranych przykładach z terenu diecezji bydgoskiej (1945-1989). Zarys zagadnienia. Studia Bydgoskie 4: 223-256.

Tomaszewski, J. (1985). Rzeczpospolita wielu narodów. Warszawa.

Zieliński, M. (2008). Wykładnia prawa. Zasady, reguły wskazówki. Warszawa.

\section{THE REVENDICATION OF PROPERTY OF THE EVANGELICAL-UNION CHURCH: AN EXAMPLE FROM THE WIELKOPOLSKA PROVINCE}

\section{Sum mary}

The article discusses issues related to the revendication of the property of the Evangelical-Union Church. The regulatory proceedings initiated in connection with the real property located in the territory of the Wielkopolska Province serve as an example. To this end, the author analyzes the issue related to the succession of the powers of the Evangelical-Union Church for the benefit of the Evangelical-Augsburg Church, and the possibility of asserting claims against the State Treasury and local governments. In addition, the article presents an analysis of the existing practice and case-law designated for conducting the regulatory proceedings of the Regulatory Commission, as well as of common courts and administrative costs. The author also draws attention to the consequences of provisions that regulate this issue not being precisely formulated by the legislator, thereby posing significant problems in their interpretation and application.

Keywords: revindication; reprivatization; regulatory proceedings; expropriation; ecclesiastical property 